\title{
https://doi.org/10.30853/manuscript.2020.3.38
}

\section{Ван Чао}

Влияние А. А. Мыльникова на художественную среду Китая

Статья посвящена исследованию влияния творчества художника-реалиста А. А. Мыльникова на китайскую масляную живопись. Растущий интерес к его художественно-педагогической деятельности нашел воплощение в выставке "Дорога к мастеру: к 100-летию со дня рождения А. А. Мыльникова" (2019) в Шанхайском музее живописи его имени. Для характеристики тематики произведений мастера выполнен композиционнохудожественный анализ его работ, выделены жанровые пристрастия и творческие взгляды, нашедшие воплощение на всем протяжении его художественной деятельности. Сделаны выводы о значении творчества А. А. Мыльникова для художественной среды КНР

Адрес статьи: www.gramota.net/materials/9/2020/3/38.html

\section{Источник}

\section{Манускрипт}

Тамбов: Грамота, 2020. Том 13. Выпуск 3. С. 189-194. ISSN 2618-9690.

Адрес журнала: www.gramota.net/editions/9.html

Содержание данного номера журнала: www.gramota.net/materials/9/2020/3/

\section{() Издательство "Грамота"}

Информация о возможности публикации статей в журнале размещена на Интернет сайте издательства: www.gramota.net Вопросы, связанные с публикациями научных материалов, редакция просит направлять на адрес: hist@gramota.net 


\title{
Теория и история искусства
}

\section{Theory and History of Art}

\author{
УДК $7 ; 5527.75 .02$ \\ https://doi.org/10.30853/manuscript.2020.3.38
}

Дата поступления рукописи: 23.01.2020

Статья посвящена исследованию влияния творчества художника-реалиста А. А. Мыльникова на китайскую масляную живопись. Растущий интерес к его художественно-педагогической деятельности нашел воплощение в выставке "Дорога к мастеру: к 100-летию со дня рождения А. А. Мыльникова» (2019) в Шанхайском музее живописи его имени. Для характеристики тематики произведений мастера выполнен композиционно-художественный анализ его работ, выделены жанровые пристрастия и творческие взгляды, нашедшие воплощение на всем протяжении его художественной деятельности. Сделаны выводы о значении творчества А. А. Мыльникова для художественной среды КНР.

Ключевые слова и фразы: Андрей Андреевич Мыльников (1919-2012); выставка «Дорога к мастеру: к 100-летию со дня рождения А. А. Мыльникова»; Шанхайский музей живописи имени А. А. Мыльникова; масляная живопись; пейзаж; портрет; обнаженная натура.

\section{Ван Чао}

Российский государственный педагогический университет имени А. И. Гериена, г. Санкт-Петербург 1647290948@qq.com

\section{Влияние А. А. Мыльникова на художественную среду Китая}

Актуальность исследования определяется растущим интересом к творчеству А. А. Мыльникова, чья школа повлияла не только на российскую художественную среду, но и оказала значительное влияние на развитие в КНР живописи маслом. «На протяжении многих лет выполняя важную роль в китайско-российских художественных отношениях, Мыльников внес большой вклад в развитие китайского изобразительного искусства» $[8$, с. 45]. Мастер считал, что традиции академической школы помогают молодым художникам расти профессионально, совершенствовать навыки и находить свой стиль. А его неустанный поиск новых техник, методов создания художественного образа стал примером для многих художников.

Имя мастера известно и в Китае. Например, китайские выпускники мастерской профессора А. А. Мыльникова Су Гаоли, Гу Цзун, Сунь Тао, Дай Шихэ и Ван Теню по возвращении в КНР распространяли знания, полученные в мастерской монументальной живописи: организовывали выставки, писали исследовательские работы, посвященные творчеству их учителя А. А. Мыльникова. Например, в 2004 г. была открыта персональная выставка мастера в Шанхайском художественном музее. Отдельные работы А. А. Мыльникова участвовали в выставках в Китае: «Выставка современной масляной живописи СССР» (1984), «Шедевры живописи Института имени И. Е. Репина и произведения русского мастера А. А. Мыльникова» (2004), «Произведения русского современного художника А. А. Мыльникова» (2007) и др. В 2010 г. в Шанхае был открыт частный музей имени А. А. Мыльникова. В 2013 г. организована персональная выставка «Моя дорога живописи: выставка пейзажей Су Гаоли», в которой выпускник мастерской А. А. Мыльникова с благодарностью вспоминает уроки учителя.

Цель статьи - определить значение художественно-педагогической деятельности А. А. Мыльникова для современной китайской живописи маслом.

Задачи:

- изучить основные источники, связанные с художественно-педагогической деятельностью А. А. Мыльникова;

- проанализировать основные работы мастера на примере выставки в Шанхайском музее живописи имени А. А. Мыльникова, используя метод композиционно-художественного анализа;

- охарактеризовать роль А. А. Мыльникова в распространении знаний о масляной живописи в Китае.

Научная новизна заключается в том, что впервые проанализирована современная выставка работ А. А. Мыльникова, организованная в Китае, где растет интерес к творческим изысканиям мастера, а его методы преподавания используются в художественных учреждениях КНР. Также освещено влияние творчества А. А. Мыльникова на китайскую живопись. 
Художественное наследие А. А. Мыльникова (1919-2012) включает монументальные фрески и мозаики, живописные пейзажи и портреты, натюрморты, а также скульптуру и графику. Творчество мастера основано на реалистических традициях, но не чуждо экспериментам и непрестанному поиску самобытных методов создания целостного и гармоничного художественного произведения. Его работы хранятся в Государственном Русском музее, Государственной Третьяковской галерее, а также во многих музеях мира. Например, в Шанхайском музее живописи имени А. А. Мыльникова, созданном в Китае в 2010 году г-ном Ша Айдэ, находится богатая коллекция работ, охватывающих различные периоды творчества художника. В частном собрании хранится порядка 200 произведений мастера, выполненных в технике масляной живописи [13]. Музей стал известным местом проведения совместных культурных мероприятий России и Китая.

Известный китайский архитектор г-н Ша Айдэ, заинтересовавшийся творчеством А. А. Мыльникова, собирает и демонстрирует народу Китая выдающееся русское живописное искусство, воплотившее в себе духовные особенности и искания художников. Знакомство с зарубежным искусством и культурный обмен между Китаем и Россией помогают развить вкус и творческие способности молодых художников КНР, постичь законы красоты и гармонии природы. Именно в работах А. А. Мыльникова можно увидеть, что гармония есть «целостность, органичность, единство всего на основании любви и добра. Гармония в произведении искусства - это наилучший порядок слов, красок, вещей, звуков, наиболее точно, полно, просто и сложно выражающий душевное состояние мысли и чувства творца» [5, с. 3]. Китайская молодежь может встретиться с приглашенными мастерами искусства, учиться на практике в музее, сопоставлять и анализировать русскую живопись и ее влияние на китайское изобразительное искусство.

В ходе интервью г-н Ша Айдэ рассказал автору данной статьи, почему создал бесплатный музей и начал активную выставочную деятельность: «Во-первых, потому что это проект культурного обмена... во-вторых, это позволит большему количеству людей увидеть русские картины, войти в контакт с хорошими произведениями искусства и обогатить художественную и культурную жизнь нашего народа; в-третьих, хочу максимально помочь молодежи. Молодежь может внести больший вклад в распространение и продвижение искусства» (интервью из личного архива автора статьи. - Ван Чао). Подобная личная инициатива не только способствует укреплению культурных связей, но и формирует своеобразное образовательное пространство для обсуждения и лучшего понимания другой культуры.

2019 год можно считать знаковым по нескольким причинам: в этом году отмечаются 70-летие со дня основания Нового Китая и 70-летие установления дипломатических отношений между Китаем и Россией. Помимо этого, 2019 год - год столетнего юбилея А. А. Мыльникова, что стало поводом к открытию в музее выставки «Дорога к мастеру: к 100-летию со дня рождения А. А. Мыльникова». На выставке представлены портреты, пейзажи и жанровые картины, выполненные в различные периоды творчества художника. Выставка наглядно продемонстрировала поиск гармонии, красоты в окружающем мире, обращение к проблеме нравственности и духовности человека, показала влияние творчества мастера на живопись Китая.

Обратимся к ряду примеров. Среди работ А. А. Мыльникова многократно встречается образ обнаженного женского тела. Жанр ню всегда был популярен у художников. Не остался в стороне и А. А. Мыльников, в 1970 году написавший «Обнаженную с белым полотенцем» $(103$ х 83, 1970). Поиск идеального женского образа всегда интересовал художника, который говорил, что «самое прекрасное в жизни - красота, чистота женского тела, гармоничность этого божественного создания» [1, с. 10]. В представленной работе (см. Рис. 1) преобладают белый, красный, охристый цвета, которые передают чистоту и нежность женщины, только что принявшей ванну. Румянец на ее лице, влажная кожа переданы уверенными и свободными мазками. Белоснежное полотно, которое только что покрывало тело женщины, написано легко, тонкой кистью. Выразительные и уверенные мазки позволяют зрителям увидеть красоту человеческого тела, проникнуться загадочностью женского образа в представлении художника.

А. А. Мыльников на протяжении всей жизни стремился воссоздать на холсте, в портретах и жанровых работах, неувядающую красоту, чистоту и гармоничность женского тела, удивительных женских образов.

В портретах А. А. Мыльников воплощал богатый внутренний мир своих героев, демонстрируя их эмоции и чувства. Как считает В. Б. Блэк, он «стремится к раскрытию характеров людей, к выявлению индивидуальных особенностей человека. В них полностью отсутствует внешняя эффектность. Композиция обычно очень проста и подчинена тому, чтобы сосредоточить внимание на лице человека» [2, с. 32]. Портрет «Ариша» $(65$ х 49, 2000$)-$ жены художника - относится к его поздним работам. Он был написан через год после ее смерти. Ариша (Ария Георгиевна) предстает перед зрителем нежной и загадочной. Соединив собственные чувства и переживания, Мыльников изобразил спокойный мудрый взгляд, изящную и стройную фигуру женщины, стремясь передать свою неизмеримую любовь к супруге. Темный сине-фиолетовый фон отражает чувство глубокой печали художника по близкому человеку, на всю жизнь ставшему его музой и верным другом.

В портрете «Ю. Толубеев» $(100$ х 100, 1974) художник запечатлел умного и благородного человека, представителя русской театральной творческой интеллигенции. Окружающие его предметы искусства, сама поза дополняют образ и говорят о характере пожилого человека (см. Рис. 2). Позолоченная рама висящей за спиной актера картины, малиновая стена, черный костюм и белая рубашка привлекают внимание своим контрастом. Выражение лица знаменитого мастера сцены интересно тем, как художник передает его добрый человечный характер. В этой работе виден А. А. Мыльников - тонкий психолог и зоркий наблюдатель.

«Портрет араба в Каире» $(80$ х 66, 1959) был создан в 1959 году, когда СССР открыл выставку советского искусства в египетской столице. А. А. Мыльников присутствовал на церемонии открытия. Однако, как вспоминал директор Шанхайского музея живописи им. А. А. Мыльникова г-н Ша Айдэ, мастер решил не терять 
времени и попросил помощника найти модель для рисования. Для создания необходимого образа художник расположил мужчину сидя, со скрещенными ногами, с покрывавшей голову светлой полупрозрачной тканью и поместил керамическую бутыль на блюде на полу перед фигурой (см. Рис. 3). А. А. Мыльников умело строил композицию и продуманно объединял людей, объекты и фон как художественно-пластическую целостность. Лицо и руки темнокожего мужчины тонко прорисованы, а светлые оттенки цвета создают эффект прозрачности. Смуглое тело контрастирует с прохладным сине-белым полосатым халатом и бледным фоном, акцентируя внимание зрителя на лице и руках о чем-то задумавшегося жителя Каира. Сочетание фигуры, предметов, их цветов создает единое выразительное целое написанного непосредственно с натуры человека. Внимание к деталям анатомии, выбор сложных оттенков делают изображение живым, правдивым и гармоничным.

«Портрет китайского художника из Чунцина» $(100$ х 73,1956$)$ написан во время первого визита А. А. Мыльникова в Китай в 1956 году. Человек на картине - самый молодой и самый активный ученик, присутствовавший на мастер-классе советского художника. Прислонившись к белой стене, служащей, как и драпировка, фоном, он держит в руке веер. Вся сцена в картине была тщательно продумана, что отражает скрупулезность и профессионализм А. А. Мыльникова. Мастер утверждал, что «пластика человеческого тела есть гармоническое соединение в контрасте и взаимосвязи весовых объемов, вступающих в свою гармонию именно благодаря единой закономерности притяжения» [6, с. 21]. После продолжительной работы и корректировок художник создал образ юноши, полного энергии и энтузиазма. Его поза динамична, взгляд бодр и уверен, что отличало многих молодых людей той эпохи. Этот портрет можно назвать и обобщенным образом китайской молодежи, обучавшейся в Советском Союзе в 1950-х годах. Студенты охотно осваивали новые знания и особенности другой культуры, уделяя все свое время учебе и творчеству. Реалистические методы академической живописи, использованные художником, отражают стилистические особенности искусства 1950-х годов: героизация подвига народа в Великой Отечественной войне, вера в светлое будущее, создание образов сильных и статных молодых людей становятся частью метода социалистического реализма, распространившегося в СССР, а затем и в КНР.

Мастер портрета, исследователь характеров и настроений моделей, А. А. Мыльников был примером для многих начинающих художников. Так, ученик Су Гаоли, стажер Института живописи, скульптуры и архитектуры им. И. Е. Репина, а ныне президент Союза монументальной живописи Китая Дай Шихэ в основе своего творческого метода видел передачу индивидуальности человека, уважение к личности. Подобных принципов придерживался еще один выпускник мастерской монументальной живописи А. А. Мыльникова Ван Теню, профессор факультета живописи художественного института при Университете Цинхуа. В серии портретов он следует традициям русской академической школы и работает не только как художник, но и как психолог-наблюдатель, стараясь передать тонкие эмоциональные изменения своих моделей.

А. А. Мыльников был не только художником-монументалистом, но и художником-лириком, что особенно заметно в его пейзажах. Он родился в маленьком городке Покровске на Волге, с детства был окружен природой, что впоследствии помогло ему создать ее яркие образы. «Постижение закономерностей природы, ее органической целостности и гармонии есть путь к постижению истины в искусстве», - неустанно повторял мастер [5, с. 3].

«Прогулка» $(25$ x 34,5, 1968) - пейзаж, символизирующий Россию. Художник тонко и внимательно написал зеленые лесные деревья и траву, мелкими мазками воссоздав ощущение движения ветвей. Исполненный в синезеленых тонах цветущий лес и прогуливающаяся вдалеке женщина в белом платье полны мира и спокойствия. Глядя на это полотно, можно понять суть творческого мировоззрения А. А. Мыльникова: гармоничное сосуществование человека и природы приносит людям умиротворение и радость наслаждения красотой родной земли.

В картине «Зима» $(40$ x 48,1970$)$ заметен четкий и точный рисунок, отражающий стремление художника к ясности и простоте изображения. В заснеженном дворе фигура человека, лошади, жующие сено, и стога сена привносят в картину лирическое настроение и душевность (см. Рис. 4). Художнику удалось раскрыть очарование природы, изображая серебристо-белый зимний снег, с чувством легкой ностальгии о былом, которую можно ощутить, рассматривая голые деревья, обветшалый забор и скромные деревянные домишки не то обветшавшие сараи, не то конюшни.

На картине «Ранняя весна» $(80$ х 130, 1980) художник изобразил лес иначе: деревья под его кистью кряжистые и прямые. Мягкая изумрудно-зеленая трава, светлое небо, река и темная стена дальнего леса за озером открываются сквозь плотный ряд деревьев на переднем плане (см. Рис. 5). А. А. Мыльников создавал силуэты деревьев не линиями, а целыми цветными блоками - массой. Нечеткие, без детальной прорисовки стволы и ветви создают эффект зрительной дистанции, пространства, что повышает выразительность и живость картины. Естественный и мягкий свет придает живописи маслом акварельный эффект. В этой работе можно увидеть наблюдения художника: вот молодые деревья; они выросли до высоких, а затем были спилены, чтобы служить людям. Едва ли этим Мыльников выразил протест против вырубки лесов, но показал, как человек вторгается в природу, пытается подчинить ее своим интересам. Обращение к теме природы «позволяло мастеру выходить на глубокие философские обобщения, претворять явления окружающего мира в емкие вневременные символы» [10, с. 50]. Хотя на картине и изображена маленькая фигура человека, основной акцент сделан на природе как таковой, с ее вдохновляющей художника красотой и гармонией.

Картина «Тонкие стволы» $(39$ х 53, 1982) воссоздает образ поздней осени. Листья уже опали. Высокие деревья, пересекающие своими тонкими обнаженными стволами все пространство холста, выглядят беззащитно и одиноко (см. Рис. 6). Однако общее настроение картины, переданное теплыми оттенками светло-желтого и зеленого, скорее печально-умиротворяющее, нежели гнетущее. Использование бледно-фиолетового цвета 
речной глади производит впечатление, будто что-то тревожное движется на зрителя. Выцветшие зеленые поля и темная полоска леса на горизонте кажутся далекими и недоступными из-за деревьев, изгороди и реки, отделяющих дали, влекущие перламутровой ширью небес и чувством свободы.

На различных этапах творчества А. А. Мыльников создал пейзажи «Осенний вид» $(60$ х 60,1970$)$ и спустя три десятилетия «Вечер» (60 х 80, 2001). Композиции полотен схожи: небольшие фигуры матери и ребенка даны в движении, основное пространство картин отведено пейзажу как главному персонажу. В частности, для картины «Осенний вид» художник завысил линию горизонта, чтобы сделать акцент на состоянии осенней природы, ее настроении, ее красоте. А. А. Мыльников хорошо разбирался в техниках и стилях европейской пейзажной живописи XVII-XIX вв., в совершенстве владел мастерством работы с цветом, потому что «знание логики построения, гармонии цвета, форм, линий, света, самой фактуры холста помогает художнику донести, не расплескав, свои мысли и чувства до зрителя» [7, с. 9]. Теплый зеленый цвет варьируется множеством оттенков, выявляя разницу деталей, выделяя траву, деревья, кусты. Ярко-красная листва - примета осени, позволяющая выразить ее сложное живописное богатство.

Природный ландшафт часто встречается в работах А. А. Мыльникова, поэтому и играет роль соединения разных элементов, формирует образ и поясняет сюжет картины. «На озере» $(53$ х 39,5, 1997) - работа именно такого типа. Картина наполнена тишиной и безмятежностью. На ней изображены густые рощи, тихая гладь озера. Вдалеке виднеется рыбацкая лодка с рыбаком, на берегу сидит одинокая фигура. Земля, небо, озеро и рыбак словно сливаются в тишине. Человек и природа дополняют друг друга. Он наслаждается счастьем и покоем, которые дарит природа. Важно подчеркнуть, что «нравственной идеей одухотворен для него (А. А. Мыльникова. - Ван Чао) пейзаж, в котором не только природные предметы, но и поэтическое авторское чувство, размышление о человеке, мечте, идеале» [3, с. 9].

Подобной любовью к русскому пейзажу проникся еще один выпускник мастерской А. А. Мыльникова - китайский художник и педагог Гу Цзун, профессор Института искусства и средств массовой информации при Пекинском педагогическом университете, декан факультета художества и дизайна. Например, в работе «Золотая осень» (1997) художник передает общее настроение спокойствия, умиротворения, созерцательности и ощущение тишины, безмолвия, используя теплый колорит и создавая небольшими мазками эффект бликов на воде.

Картина «Сон» $(37$ x 48, 1999) в Шанхайском музее живописи имени А. А. Мыльникова является одной из знаковых. Причина в том, что А. А. Мыльников выразил свои личные идеи в этой работе, наглядно характеризующей особенности его зрелого творчества, в котором «свобода владения художественной формой дает возможность идеям легко воплощаться в произведении в убедительных, живых образах» [4, с. 23]. Перед зрителями на переднем плане предстает лежащая обнаженная женщина - один из любимых образов художника, на заднем плане - потрясающая колористическая комбинация бирюзового и небесно-голубого цветов (см. Рис. 7). Настроение полотна становится более мечтательным, а пространство - более глубоким. Женское тело, написанное в бледно-розовых цветах, деликатно и даже элегантно выделяется на фоне густой зеленой травы и небрежно брошенного на траву белого покрывала, на котором лежит фигура. Благодаря использованию изумрудно-зеленых и лазорево-голубых оттенков художник будто переносит зрителя в мир подсознательного, в мир сновидений. Полупрозрачная неясная фигура на дальнем плане усиливает атмосферу таинственности и словно какого-то мистицизма

В предшествующие годы А. А. Мыльников не раз пытался воплотить образ, который бы объединял человека и природу, передавал размышления художника о «гармонии чистого, естественного человека с природой... Нагота телесная - здесь нагота духовная, незащищенность, открытость “вечно женственного”, красоты перед лицом жизни» [9].

А. А. Мыльников считал неотъемлемой частью художественного процесса знание и понимание законов природы, стремление к гармонии, красоте и любви. Трудолюбие, богатый жизненный опыт, желание делиться своими знаниями и навыками служили примером для близких, учеников и коллег А. А. Мыльникова. Так, Цзинь Шанши, выпускник мастерской народного художника СССР, профессора В. М. Орешникова, считал, что «его (А. А. Мыльникова. - Ван Чао) исследование было построено на любви и понимании жизни, поэтому он никогда не уклонялся от принципов и законов искусства. На основе интеграции мысли и искусства, чувственности и рациональности, традиции и оригинальности постепенно формировался общий художественный стиль» $[12$, с. 83]. Следование реалистической традиции русской академической школы, изучение лучших западноевропейских образцов живописи и китайского традиционного искусства сочетались с его мастерством педагога, умением слушать и наставлять каждого ученика, прививая любовь к общечеловеческим ценностям. Воспитание творческой личности, способной понимать законы природы, любить свою родину, ценить добро и с уважением относиться к людям, - основные идеи, которыми руководствовался выдающийся русский художник-педагог А. А. Мыльников.

В статье впервые проанализирована современная выставка работ художника, проведенная в Шанхае, «Дорога к мастеру: к 100-летию со дня рождения А. А. Мыльникова». Создание в 2010 г. частного музея живописи имени А. А. Мыльникова и организация в нем выставок, лекций, мастер-классов говорят о непреходящем интересе китайских художников и зрителей к его творческому методу. Жанры портрета, пейзажи, работы с обнаженной натурой, которые можно увидеть в Шанхайском музее живописи имени А. А. Мыльникова, отражают этические и эстетические взгляды мастера: «Картина - организм сложный: в его рождении и создании принимают участие как чувственные, так и логические категории. Я убежден, что только в сплаве любви и жизни способен возникнуть яркий образный замысел художника» [7, с. 9]. Они не только передают его поиски красоты и гармонии, но и приглашают зрителя поразмышлять на важные философские темы. 


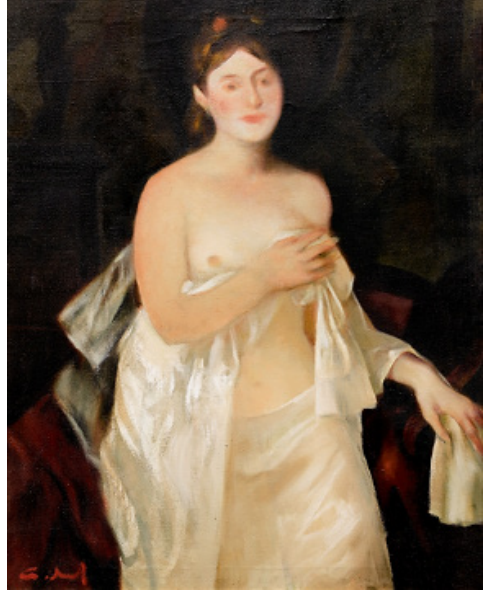

Рисунок 1. Обнаженная с бельм полотенщем. 1970

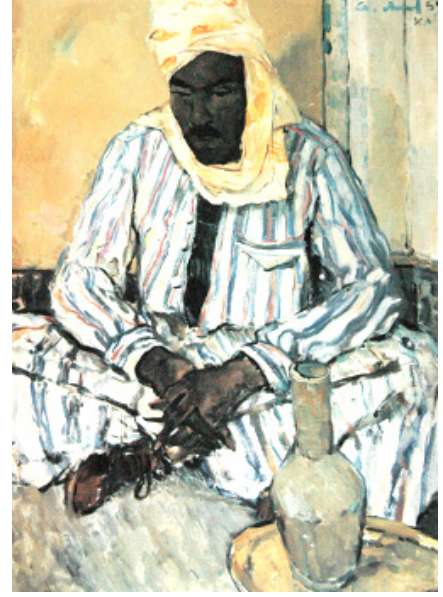

Рисунок 3. Портрет араба в Каире. 1959

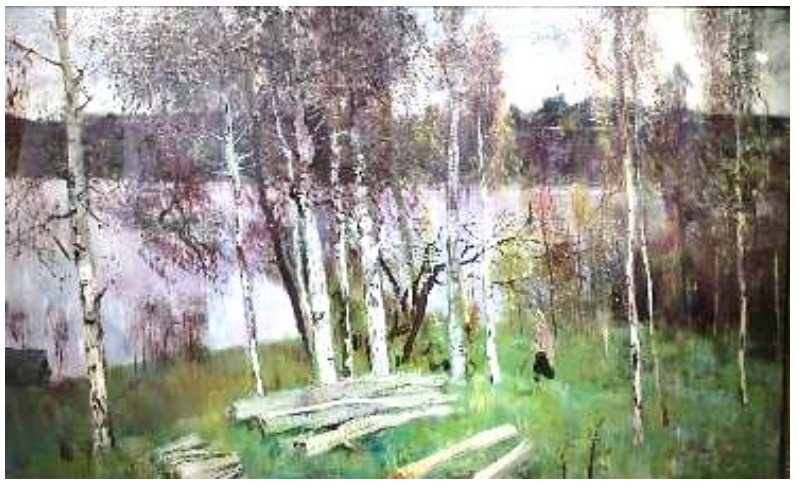

Рисунок 5. Ранняя весна. 1980

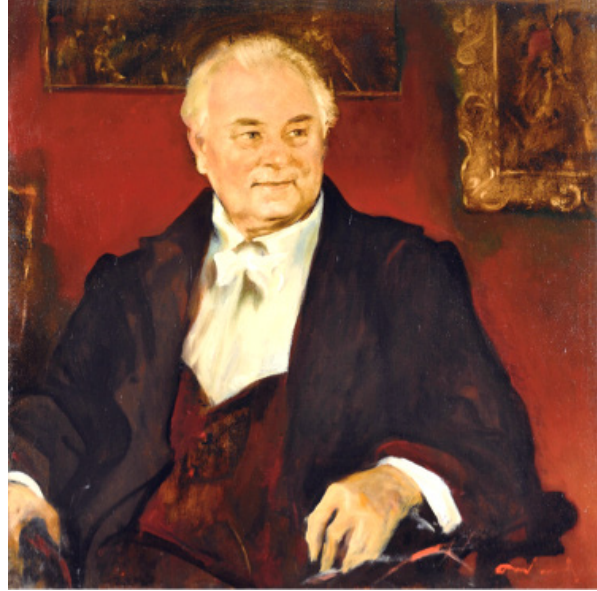

Рисунок 2. Ю. Толубеев. 1974

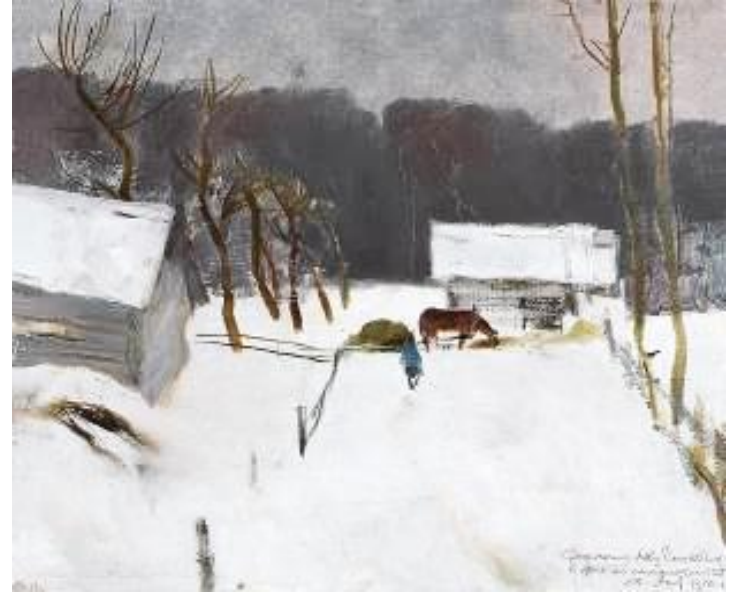

Рисунок 4. Зима. 1970

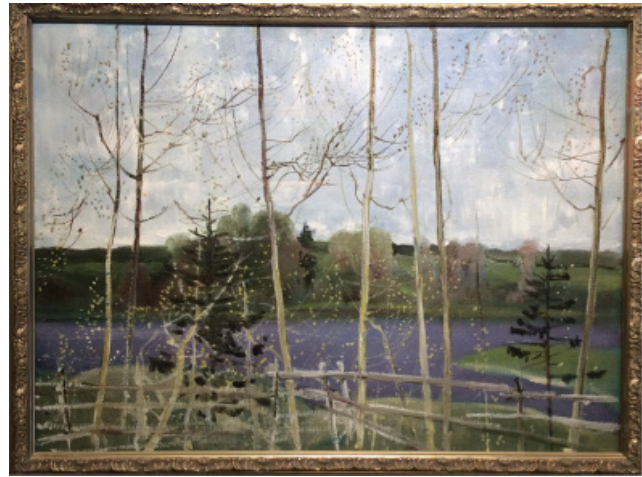

Рисунок 6. Тонкие ствольы. 1982

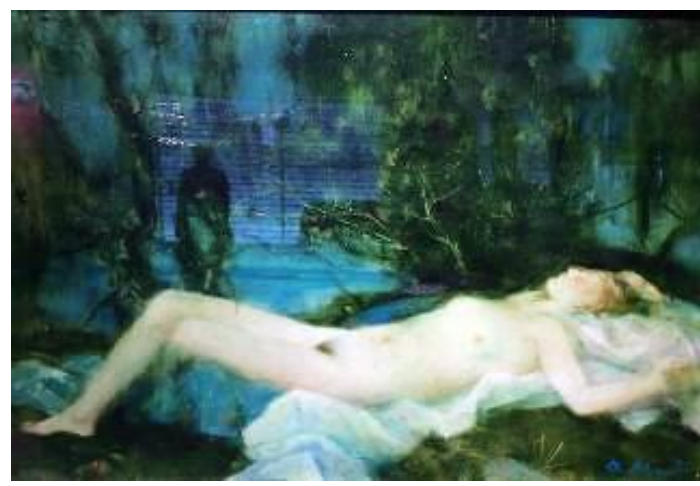

Рисунок 7. Сон. 1999 
Творческая и педагогическая деятельность А. А. Мыльникова оказала большое влияние на искусство Китая второй половины XX века. Он «воспитал огромный отряд художников, работающих ныне не только в России, но и за рубежом, в том числе в Китае» [8, с. 158]. Его глубокие портреты и проникновенные образы обнаженных, многочисленные пейзажи пользуются неизменной популярностью в китайских художественных кругах и сегодня. Лекции и мастер-классы А. А. Мыльникова во время двух визитов в Китай в 1956 и 1991 гг. способствовали началу создания коллекций работ известного русского художника, а также заложили фундамент научно-исследовательской базы его творчества.

А. А. Мыльников внес важный вклад в становление изобразительного искусства Китая, развитие реалистической школы живописи. Так, под его руководством свои дипломные работы писали Су Гаоли - будущий профессор Китайской Центральной академии художеств, известные художники Гу Цзун и Сунь Тао. После возвращения на родину китайские выпускники академической мастерской профессора Мыльникова участвовали в организации выставок его работ, исследовали его творческий путь, так как высоко ценили личность и профессионализм своего выдающегося учителя «не только потому, что он олицетворял советский реализм, но и потому, что его искусство пересекало границы и представляло своеобразный многовековой характер искусства того времени - современный характер реализма» [11, с. 84].

Большинство источников и литературы посвящены творчеству мастера и его педагогическим взглядам. Лишь немногие исследования последних лет анализируют влияние А. А. Мыльникова на китайскую живопись маслом. Например, работа Нин Бо о китайских выпускниках Института имени И. Е. Репина [8]. Однако глубокого и всестороннего анализа творчества А. А. Мыльникова и его роли в развитии живописи Китая не проведено. Данная работа может стать первым этапом обобщения материала касательно деятельности мастера и его вклада в развитие масляной живописи КНР. В дальнейшем важно изучить выпускные и учебные работы китайских студентов мастерской монументальной живописи А. А. Мыльникова, проследить их творческий и педагогический путь в КНР. Также статья может быть использована при исследовании истории российского (советского) и китайского высшего художественного образования; при организации художественных выставок реалистической живописи в Китае, составлении курса лекций по истории китайской реалистической живописи второй половины XX - начала XXI в., в описании культурных и художественных связей Китая и России.

Список источников

1. Андрей Мыльников: каталог выставки «Варианты» / сост. Е. М. Елизарова. СПб.: Изд-во Ин-та им. И. Е. Репина, 2007. $52 \mathrm{c}$.

2. Блэк В. Б. Андрей Мыльников // Искусство. 1966. № 11. С. 26-32.

3. Дмитренко А. Ф. Мир художника. Выставка А. А. Мыльникова в ГРМ // Художник. 1990. № 4. С. 6-12.

4. Мусаева Н. Ф. Педагогические взгляды А. А. Мыльникова // Вопросы художественного образования. 1984. № 36. С. 19-25.

5. Мыльников А. А. О роли преподавания живописи в воспитании художников театра и кино // Вопросы художественного образования. 1982. № 30. С. 3-6.

6. Мыльников А. А. Проблемы композиции // Вопросы художественного образования. 1982. № 27. С. 21-24.

7. Мыльников А. А. Талантливое произведение искусства - вклад в советскую культуру // Искусство. 1977. № 7. С. 9-11.

8. Нин Бо. Китайские выпускники Института имени И. Е. Репина - носители и продолжатели традиций ленинградской академической художественной школы: дисс. ... к. искусствоведения. СПб., 2010. 317 с.

9. Петров В. А. Прекрасное - рядом [Электронный ресурc]. URL: http:/andreymylnikov.com/about-painter/articles/ prekrasnoe-ryadom/ (дата обращения: 08.11.2019).

10. Современное - актуальное - вечное: круглый стол по материалам выставки к 100-летию со дня рождения Андрея Андреевича Мыльникова (1919-2012) // Петербургские искусствоведческие тетради: статьи по истории искусства. СПб.: Спектр, 2019. № 56. С. 44-60.

11. 孙涛外国大画家-梅尔尼科夫。南昌 : 江西美术出版社, 2007. 页81-85 (Сунь Тао. Великий зарубежный художник А. А. Мыльников. Наньчан, 2007. С. 81-85).

12. 全山石 艺术常青树//济南：山东艺术学院出版社, 2007. 页81-93 (Цзинь Шаньши. Вечнозеленое дерево искусства. Цзинань, 2007. С. 81-93).

13. 上海梅尔尼科夫美术馆 (Шанхайский музей живописи им. А. А. Мыльникова) [Электронный ресурс]. URL: http://www.sbdart. net/menkfzpcls (дата обращения: 17.01.2020).

\title{
A. A. Mylnikov's Influence on China's Artistic Environment
}

\author{
Wang Chao \\ The Herzen State Pedagogical University of Russia, Saint Petersburg \\ 1647290948@qq.com
}

The article examines influence of the realistic painter A. A. Mylnikov on the Chinese oil painting. The exhibition "The Road to the Artist: To the $100^{\text {th }}$ Anniversary of A. A. Mylnikov" (2019) in Shanghai Art Museum testifies to the growing interest for his artistic and pedagogical heritage. The paper provides a compositional and artistic analysis of A. Mylnikov's works, identifies his genre preferences and creative conceptions he followed throughout his creative career. Conclusions are made about influence of A. A. Mylnikov's creative work on China's artistic environment.

Key words and phrases: Andrei Andreevich Mylnikov (1919-2012); exhibition "The Road to the Artist: To the $100^{\text {th }}$ Anniversary of A. A. Mylnikov"; Shanghai Art Museum; oil painting; landscape; portrait; nude. 